\title{
PERBANDINGAN DESAIN RUKO DI INDONESIA DITINJAU DARI ASPEK SOSIAL DAN PEMBENTUKAN KOMUNITAS
}

\author{
Nathalia Yunita Sugiharto \\ Magister Arsitektur, Program Pascasarjana, Universitas Katolik Parahyangan, Bandung, \\ Jl. Merdeka, No. 30, Bandung - Indonesia \\ Email: liajune1992@gmail.com
}

\begin{abstract}
Abstrak
Keberadaan ruko di Indonesia sudah dimulai pada abad ke 17 pada Era kolonial tipe long plot yang dibawa oleh para pedagang Cina. Bentuk ruko dianggap sebagai solusi atas meningkatnya kepadatan penduduk di Indonesia dan lahan yang semakin sempit. Bangunan ruko kemudian berkembang dengan bentuk yang semakin menyesuaikan dengan perkembangan zaman. Seiring dengan perkembangannya, muncul kendala pada desain ruko saat ini. Bangunan ruko yang pada dasarnya menampung dua fungsi yakni hunian dan toko mulai menghilang. Fungsi toko menjadi dominan dan fungsi rumah mulai ditinggalkan. Salah satu penyebab dari ditinggalkannya fungsi hunian adalah kebutuhan sosial dari penghuni yang tidak terpenuhi oleh desain ruko yang ada pada saat ini. Metode penelitian yang digunakan adalah komparatif dengan membandingkan desain ruko pada era kolonial tipe long plot dengan desain ruko yang umum ditemukan di Indonesia. Berdasarkan hasil studi didapatkan bahwa desain ruko pada era kolonial tipe long plot mampu mengakomodasi fungsi sosial antar penghuni di kawasan ruko atau mampu menciptakan komunitas sedangkan desain ruko yang umum ditemukan di Indonesia menitikberatkan dari segi ekonomi (cepat terjual) sehingga mengesampingkan kebutuhan hunian dalam desainnya. Studi ini diharapkan dapat memberikan manfaat dalam mendesain ruko ke depannya dan dapat menyumbangkan pengetahuan dalam ranah arsitektur.
\end{abstract}

Kata kunci: ruko, sosial, fasilitas, komunitas, perkembangan

\begin{abstract}
Title: Indonesian Shophouse Design Development based on the Establishment of Community and Social Aspect

The existence of shophouse in Indonesia has been started in the 17th century at the Colonial Era brought by Chinese traders. Shophouse is considered as a solution of the increasing density of population in Indonesia and land limitation. Shophouse typology adapt along with time and its surroundings. Along with its development, nowadays shophouse's design had its own problem. Basically shophouse is supposed to accomodate two functions which is residential and stores but its residential function become less dominant than its commercial function. One of the causes is the shophouse design can't meet the resident's social needs satisfaction. Method that used in this research is comparative by comparing shophouse design in Colonial era with shophouse design that commonly found in Indonesia. Based on the study, it showed that the shophouse design in Colonial era was able to accommodate social functions among the inhabitants while the shophouse design that is commonly found in Indonesia focused in terms of economy (how quickly sold) and ignore the residential needs in their design. The study is expected to provide benefits in shophouse design in future and can contribute the knowledge in the realm of architecture.
\end{abstract}

Keywords: shophouse, social, facilities, community, development 


\section{Pendahuluan}

Bangunan ruko merupakan gabungan dari fungsi hunian dan fungsi komersil yang ada di Indonesia sejak era kolonial. Bangunan ruko di Indonesia sangat berkaitan erat dengan masyarakat Cina. Hal ini bermula dari kegiatan utama masyarakat Cina di Indonesia yaitu berdagang yang terbentur dengan keterbatasan lahan sehingga terbentuklah bangunan ruko untuk mengakomodasi kegiatan berdagang serta berhuni. (Widodo, 1990).

Di Indonesia saat ini, bangunan tipe ruko cukup menjamur dan sering ditemukan bergabung dengan fungsi perumahan maupun fungsi komersil. Namun pada kenyataannya, bangunan ruko yang seharusnya mengakomodasi fungsi rumah dan toko tidak dapat berfungsi sebagaimana harusnya. Fungsi rumah atau hunian pada ruko jarang digunakan oleh pemiliknya. Berdasarkan penelitian, ditemukan hanya sekitar $10 \%$ bangunan ruko yang digunakan sebagai toko dan rumah oleh pemilik rukonya. Padahal bangunan ruko dibuat sebagai solusi dari keterbatasan lahan serta dapat mempersempit jarak antar kantor dengan hunian sehingga dapat mengurangi kemacetan dan waktu tempuh.

Salah satu faktor yang menyebabkan tidak berfungsinya hunian dalam ruko adalah kesan hidup yang terpisah dari orang lain (individualis). Orang merasa tidak nyaman tinggal di dalam ruko karena tidak adanya interaksi antar penghuni ruko (terkesan tidak ada tetangga) yang kemudian berpengaruh pada munculnya rasa tidak aman tinggal di dalam ruko sehingga orang banyak menggunakan ruko sebagai tempat berdagang bukan sebagai tempat berhuni. Hal ini membuktikan bahwa desain ruko yang umum ditemukan saat ini di Indonesia belum memadai baik secara lingkungan maupun unitnya terutama dari segi kebutuhan sosial dari penghuninya.

Namun pada era kolonial tipe long plot, fenomena tidak dihuninya ruko tidak terjadi. Pada kompleks ruko era kolonial tipe long plot, masyarakat tetap bisa melakukan aktivitas sosial dan dapat berinteraksi dengan tetangga di sekitarnya sehingga kehidupan komunitas di dalam kompleks menjadi hidup tidak seperti pada ruko yang ada di Indonesia saat ini.

Berdasarkan kedua fenomena yang bertolak belakang tersebut, diperlukan penelitian mengenai desain ruko pada era kolonial tipe long plot dan desain ruko yang umum ditemukan di Indonesia. Penelitian dilakukan untuk mempelajari desain pada bangunan ruko era kolonial tipe long plot yang dapat hidup secara sosial. Melalui penelitian ini, kedua desain akan dibandingkan untuk ditemukannya desain ruko yang dapat memicu terjadinya sebuah komunitas sehingga bangunan ruko yang ada saat ini dapat berfungsi secara ideal sebagai hunian dan sebagai toko. Diharapkan hasil penelitian dapat digunakan sebagai bahan pertimbangan dalam merancang bangunan ruko yang 
dapat berfungsi secara ideal sesuai dengan tujuannya.

\section{Materi dan Metode}

Penelitian didasarkan pada metode deskripsi yakni menggambarkan fenomena yang terjadi dan mengacu pada fakta yang terjadi di lapangan dengan bantuan gambar, foto serta literatur (untuk desain ruko era kolonial tipe long plot) serta metode komparatif yang digunakan untuk membandingkan desain ruko pada era kolonial tipe long plot dengan desain ruko yang umum ditemukan saat ini di Indonesia. Diharapkan dengan terjadinya perbandingan akan diketahui penyebab mengapa desain ruko yang ada saat ini tidak dapat berfungsi secara sosial seperti pada desain ruko pada era kolonial tipe long plot.

\section{Kasus Studi}

Objek penelitian terbagi atas dua yakni ruko era kolonial tipe long plot serta ruko yang umum ditemukan saat ini di Indonesia. Objek ruko era kolonial tipe long plot diambil dari penelitian yang berjudul Urban Development and the Chinese Settlements in the Northern Coast of Java (Widodo, 1990) dengan tipe ruko yang memiliki orientasi 2 arah dalam hal ini terlihat pada tipe compound dan long plot sedangkan objek ruko yang umum ditemukan saat ini di Indonesia diambil dari ruko Singgasana Pradana di Kota Bandung.

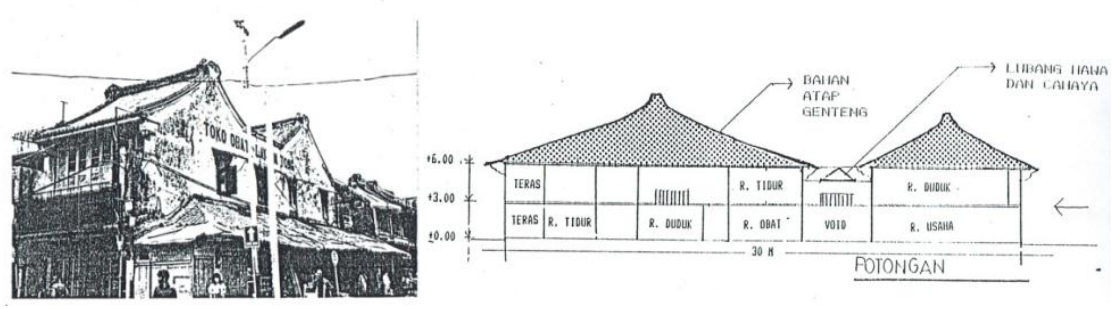

Gambar 1. Objek penelitian ruko era Kolonial

Sumber: Widodo, 1990

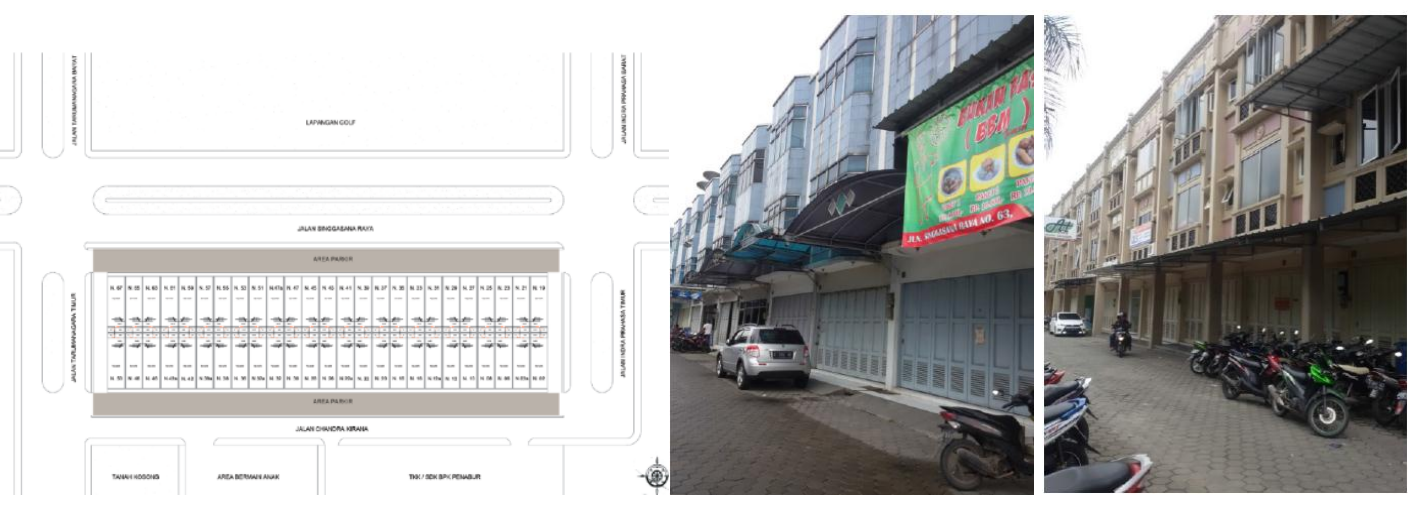

Gambar 2. Objek penelitian ruko tipe saat ini Sumber: Singgasana Pradana Bandung, 2016 


\section{Langkah Analisis}

Langkah analisis dalam penelitian terbagi menjadi tiga yakni :

1. Analisis mengenai desain ruko era kolonial tipe long plot dilihat dari penyusunan massa dengan fasilitas penunjangnya, orientasi, hirarki ruang, aksesibilitas dan kaitannya dengan aspek sosial.

Hal ini dipelajari dari sumber literatur mengenai ruko pada era kolonial tipe long plot.

2. Tahap kedua adalah analisa mengenai desain ruko yang umum ditemukan saat ini ditinjau dari sudut yang sama dengan analisa desain ruko era kolonial tipe long plot.

3. Tahap ketiga adalah membandingkan desain ruko era kolonial tipe long plot dengan desain ruko umum yang ditemukan saat ini dan menemukan kekurangannya yang berakibat pada tidak berfungsinya aspek sosial dalam bangunan ruko.

Berikut adalah pokok analisis yang dijabarkan dalam bentuk skema di bawah ini :

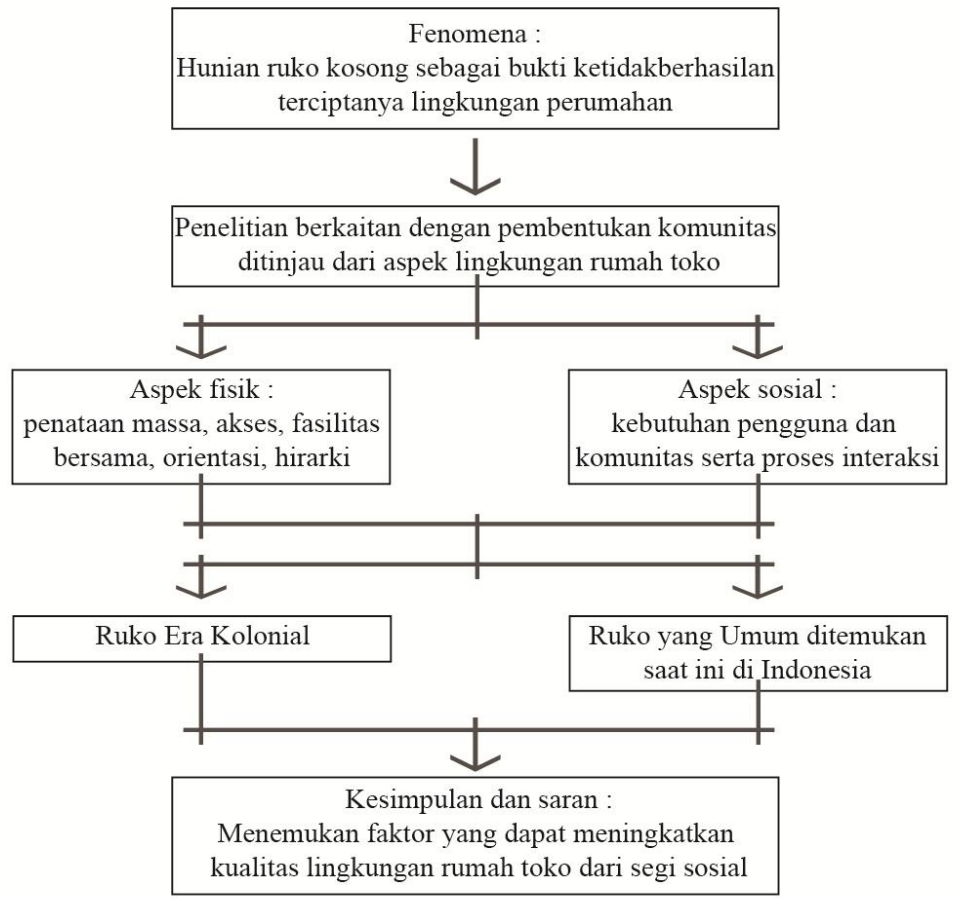

Gambar 3. Skema pokok analisis perkembangan ruko ditinjau dari aspek sosial dan pembentukan komunitas

Sumber: Hasil Analisis, 2016

Dalam penelitian dibutuhkan data yang menunjang hasil penelitian seperti data primer yang berupa gambar lapangan, foto, hasil angket wawancara untuk data desain rancangan ruko yang banyak ditemukan saat ini di Indonesia serta 
data sekunder dari literatur seperti buku teks dan dokumen yang dapat membantu memahami desain rancangan ruko pada era kolonial tipe long plot.

\section{Hasil dan Pembahasan}

Secara garis besar sebuah bangunan tidak hanya dilihat secara fisik dimana bangunan dapat berdiri tetapi pengguna harus merasa nyaman berada di dalam bangunannya atau dalam kata lain kebutuhan pengguna bangunan secara psikologis telah terpenuhi. Dalam rumah kebutuhan psikologis dapat tertuang dalam kebutuhan sosial karena manusia pada dasarnya adalah makhluk sosial. Hal ini dapat tercapai ketika sebuah lingkungan hunian memiliki desain, fasilitas bersama atau sarana prasarana yang dapat memicu terjadinya sebuah komunitas sehingga terjadi kehidupan dalam lingkungannya.
Objek penelitian akan dibagi berdasarkan penataan massa, akses, orientasi, dan hirarki ruang yang menunjang beroperasinya sebuah komunitas dalam lingkungan perumahan ruko.

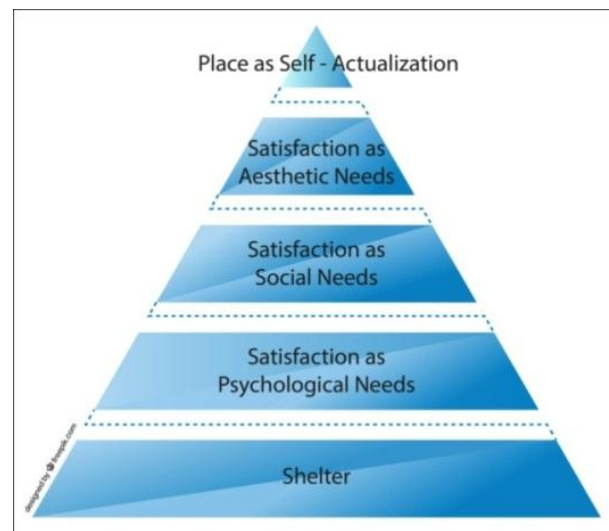

Gambar 4. Diagram psikologi desain Sumber: Some Like Home, Using Design Psychology to Create Ideal Places

\section{Penataan Massa}

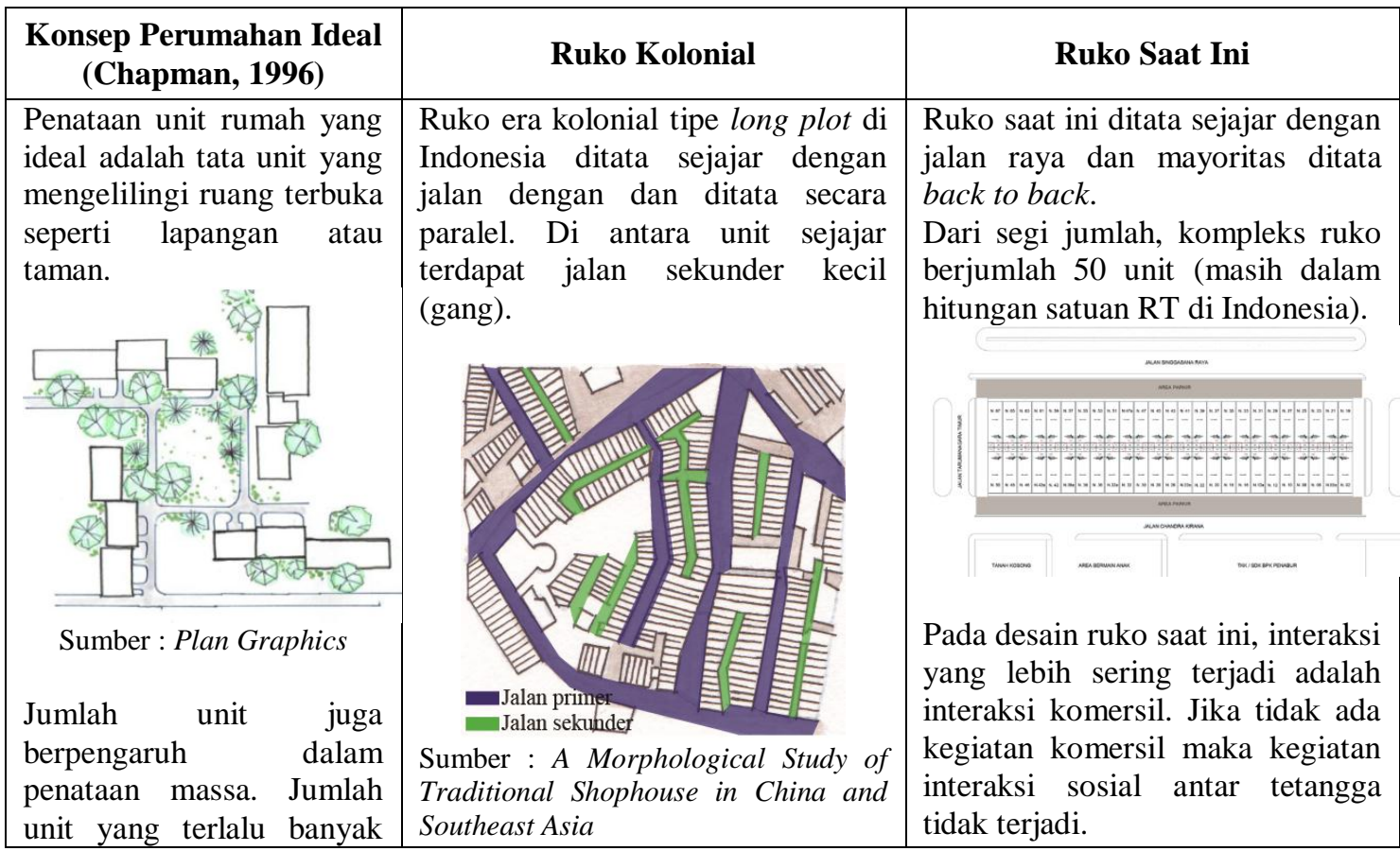




\begin{tabular}{|c|c|c|}
\hline $\begin{array}{l}\text { dalam 1 kelompok akan } \\
\text { menghilangkan kesan } \\
\text { hidup berkelompok. Oleh } \\
\text { karena itu berikut adalah } \\
\text { jumlah yang disarankan } \\
\text { dalam } 1 \text { lingkungan : } 20 \\
\text { unit (internasional) atau } \\
15 \text { - } 30 \text { unit hingga maks. } \\
75 \text { unit (satuan RT di }\end{array}$ & $\begin{array}{l}\text { Interaki gloвs } \\
\text { kuning) dengan interaksi antar } \\
\text { penghuni (area merah) memiliki } \\
\text { ruangnya masing-masing dan tidak } \\
\text { tercampur. Interaksi antar } \\
\text { penghuni diwadahi oleh gang. }\end{array}$ & $\begin{array}{l}\text { lingkan dengan konsep } \\
\text { ahan ideal, desain ruko saat } \\
\text { ak menerapkan hal tersebut } \\
\text { tidak ada ruang terbuka } \\
\text { mampu menjadi wadah }\end{array}$ \\
\hline \multicolumn{3}{|c|}{$\begin{array}{l}\text { Analisa Penataan Massa dan Kaitannya dengan Peluang Interaksi : } \\
\text { Permasalahan desain yang mengakibatkan hilangnya kesan hidup berkelompok adalah jumlah unit } \\
\text { yang terlalu banyak dalam satu lingkungan dan penataan massanya yang cenderung linear. Kedua tipe } \\
\text { ruko (kolonial dan saat ini) disusun dengan penataan linear di sepanjang jalan utama, yang } \\
\text { membedakan keduanya adalah ruang diantara unit ruko. Kegiatan penghuni ruko kolonial dapat } \\
\text { terwadahi oleh adanya gang di belakang unitnya sedangkan ruko saat ini tidak menyediakan wadah } \\
\text { untuk interaksi antar penghuninya. Jumlah unit dalam satu jajar ruko ada di dalam kisaran satuan RT di } \\
\text { Indonesia namun akibat penataannya yang linear, interaksi antar penghuni unit ruko tidak terjadi. } \\
\text { Kesimpulan dari kedua desain ruko yang ada adalah ruko kolonial dan ruko saat ini tidak maksimal } \\
\text { dalam menerapkan konsep perumahan ideal. }\end{array}$} \\
\hline
\end{tabular}

Tabel 1. Analisis penataan ruko Kolonial dan ruko saat ini

Sumber: Hasil Analisis, 2016

\section{Aksesibilitas dan Hirarki Ruang}

\begin{tabular}{|c|c|c|}
\hline $\begin{array}{c}\text { Konsep Perumahan } \\
\text { Ideal (Chapman, } \\
\text { 1996) }\end{array}$ & Ruko Kolonial & Ruko Saat Ini \\
\hline $\begin{array}{l}\text { Terdapat tiga jenis } \\
\text { akses ideal dari cluster } \\
\text { menuju unit rumah } \\
\text { yakni akses langsung, } \\
\text { akses ruang terbuka dan } \\
\text { akses jalan sekunder. } \\
\text { Berdasarkan hasil } \\
\text { survei, mayoritas orang } \\
\text { kurang menyukai atau } \\
\text { tidak nyaman dengan } \\
\text { akses ruko yang } \\
\text { menyatukan akses } \\
\text { hunian dan tokonya. } \\
\text { Hirarki ruang berkaitan } \\
\text { erat dengan }\end{array}$ & $\begin{array}{l}\text { Ruko era kolonial tipe long plot di } \\
\text { Indonesia memiliki dua akses dimana } \\
\text { akses toko dan akses hunian terpisah } \\
\text { sehingga tidak terjadi lintas fungsi } \\
\text { diantara keduanya. } \\
\text { Dengan dua akses langsung menuju } \\
\text { masing-masing fungsi. Penghuni }\end{array}$ & $\begin{array}{l}\text { Ruko saat ini hanya memiliki satu } \\
\text { akses untuk kegiatan hunian dan }\end{array}$ \\
\hline
\end{tabular}




\begin{tabular}{|c|c|c|}
\hline $\begin{array}{l}\text { adi nyan } \\
\text { nuh } \\
\text { udahan } \\
\text { rumah } \\
\text { bersa } \\
\text { me } \\
\text { gunaan }\end{array}$ & $\begin{array}{l}\text { h } \\
\text { hi } \\
\text { hi } \\
\text { in }\end{array}$ & $\begin{array}{l}\text { Ko seningga peng } \\
\text { elewati bagian } \\
\text { enuju area luar } \\
\text { baliknya. } \\
\text { enurut responden } \\
\text { engurangi kenyam }\end{array}$ \\
\hline \multicolumn{3}{|r|}{$\begin{array}{l}\text { ng Interaksi : } \\
\text { at ini tidak memiliki perbedaan yang } \\
\text { anit. } \\
\text { temukan saat ini membuat penghuni } \\
\text { i area komersil (ruang publik) untuk } \\
\text { s untuk berkegiatan di luar rumah } \\
\text { Selain itu, untuk membawa tamu ke } \\
\text { ruko. Hal ini juga merupakan salah } \\
\text { rena ada terjadi percampuran hirarki } \\
\text { temukan bahwa akses komersil dan } \\
\text { sehingga penghuni unit ruko dapat } \\
\text { sial dengan tetangga unit lain) tanpa }\end{array}$} \\
\hline
\end{tabular}

Tabel 2. Analisis aksesibilitas dan hirarki ruang ruko Kolonial dan ruko saat ini Sumber: Hasil Analisis, 2016

\section{Fasilitas Bersama dan Orientasi}

\begin{tabular}{|l|l|l|}
\hline \multicolumn{2}{|c|}{ Konsep Perumahan } \\
Ideal (Chapman, 1996)
\end{tabular}




\begin{tabular}{|c|c|c|}
\hline $\begin{array}{l}\text { Sebuah lingkungan } \\
\text { perumahan berkelompok } \\
\text { harus dilengkapi dengan } \\
\text { fasilitas bersama yang } \\
\text { dapat dinikmati oleh } \\
\text { publik untuk menunjang } \\
\text { kegiatan berhuni. } \\
\text { Secara global, disarankan } \\
\text { perumahan dilengkapi } \\
\text { dengan ruang terbuka dan } \\
\text { fasilitas rekreasi seperti } \\
\text { ruang olahraga dan taman } \\
\text { Di Indonesia, SNI } \\
\text { menetapkan sebuah RW } \\
\text { harus memberikan balai } \\
\text { pertemuan, } \\
\text { posyandu, tempat ibadah, } \\
\text { toko, taman dan jaringan } \\
\text { utilitas. }\end{array}$ & $\begin{array}{l}\text { Pada ruko era kolonial tipe long } \\
\text { plot, posisi fasilitas bersama biasa } \\
\text { bersatu dengan lingkungan } \\
\text { perumahannya atau penghuni } \\
\text { memanfaatkan gang atau jalan } \\
\text { sekunder sebagai fasilitas bersama } \\
\text { untuk bermain atau sekedar } \\
\text { mengobrol dengan tetangga. } \\
\text { Dibandingkan dengan konsep } \\
\text { perumahan ideal, desain ruko era } \\
\text { kolonial ini cukup memenuhi } \\
\text { kriteria. Oleh karena itu, terjadi } \\
\text { interaksi antar penghuni unit ruko } \\
\text { di ruang luar bersama walaupun } \\
\text { tidak berbentuk seperti taman atau } \\
\text { fasilitas rekreasi yang memadai. }\end{array}$ & $\begin{array}{l}\text { Ruko saat ini yang ditata linear } \\
\text { jarang dilengkapi dengan fasilitas } \\
\text { bersama yang menunjang sebagai } \\
\text { wadah interaksi antar penghuni unit } \\
\text { ruko seperti yang terdapat dalam } \\
\text { SNI. } \\
\text { Selain itu, jika unit ruko memiliki } \\
\text { fasilitas bersama yang bersatu } \\
\text { dengan perumahan di belakangnya } \\
\text { timbul permasalahan. Orientasi } \\
\text { yang hanya menghadap jalan besar } \\
\text { membuat orang tua tidak } \\
\text { mengijinkan anaknya untuk } \\
\text { bermain di luar unit. } \\
\text { Hal ini kemudian membuat fasilitas } \\
\text { bersama tidak mampu berfungsi } \\
\text { sebagai wadah interaksi. }\end{array}$ \\
\hline $\begin{array}{l}\text { an sekunder di } \\
\text { ggunakan jal } \\
\text { h kendaraan }\end{array}$ & o & $\begin{array}{l}\text { api } \\
\text { lah } \\
\text { olot } \\
\text { dak } \\
\text { ksi } \\
\text { uni } \\
\text { di } \\
\text { ang } \\
\text { dak }\end{array}$ \\
\hline
\end{tabular}

Tabel 2. Analisis fasilitas bersama dan orientasi ruko Kolonial dan ruko saat ini Sumber: Hasil Analisis, 2016

Desain ruko pada era kolonial tipe long plot terbukti dapat menghidupkan kegiatan interaksi sosial penghuni ruko dibandingkan dengan desain ruko yang banyak ditemukan di Indonesia. Walaupun wadah interaksi sosial antar unit ruko belum maksimal, keberadaan jalan sekunder di antara unit ruko linear memiliki peran penting sebagai ruang yang menjadi wadah interaksi sehingga terjadi kehidupan sosial dalam lingkungan perumahan unit ruko. Hal ini berbanding terbalik dengan kehidupan sosial pada ruko saat ini yang tidak memiliki wadah interaksi bagi penghuni unit ruko dengan tetangga yang berada di sekitarnya yang berakibat pada tidak menariknya unit ruko sebagai hunian. 


\section{Kesimpulan}

Berdasarkan hasil analisis penataan massa, aksesibilitas, hirarki ruang, fasilitas bersama dan orientasi ruko era kolonial tipe long plot dan ruko yang banyak ditemukan di Indonesia saat ini, dapat dihasilkan beberapa temuan (1) Desain awal ruko pada era kolonial tipe long plot tidak mempengaruhi desain ruko yang saat ini banyak ditemukan di Indonesia dari segi ketersediaan wadah untuk kegiatan bersama yang berdampak pada tidak berfungsinya unit ruko saat ini sebagai sebuah hunian; (2) Ruang bersama menjadi hal yang utama dalam memicu interaksi sosial antar penghuni unit ruko; (3) Akses menuju unit hunian dan toko lebih baik terpisah sehingga kedua kegiatan dapat berjalan bersama tanpa harus bersinggungan secara langsung.

Melalui telaah kasus studi, maka dapat disimpulkan jika penyediaan dan penggunaan sarana prasarana dalam bentuk ruang bersama yang dapat dinikmati oleh publik akan meningkatkan kualitas kepuasan kebutuhan sosial yang dapat menghidupkan fungsi hunian dalam ruko.

\section{Saran}

Idealnya sebuah bangunan dengan fungsi campuran dalam hal ini toko dan hunian dapat berjalan dengan baik sesuai dengan namanya. Arsitek sebagai perancang seharusnya memiliki pemahaman yang cukup mengenai desain masing-masing fungsi dan dapat menggabungkannya dengan baik sehingga desain yang dihasilkan dapat berhasil dengan baik dan dapat memenuhi kebutuhan pengguna bangunan tersebut.

\section{Daftar Pustaka}

Chapman, David. (1996). Creating Neighborhood and Places in the Built Environment. E \& FN Spon, London.

Han, Wang., Jia Beisi. (2015) " $A$ Morphological Study of Traditional Shophouse in China and Southeast Asia". Procedia - Social and Behavioral Sciences 179.

Hester Jr., Randolph T. (1984). Planning Neighborhood Space with People, second edition. Van Nostrand Reinhold Company Inc., New York.

Israel, Toby. (2003). Some Place Like Home: Using Design Psycology to Create Ideal Places. Wiley, New York.

Standar Nasional Indonesia 03-17332004, tentang Tata Cara Perencanaan Lingkungan Perumahan di Perkotaan.

Untermann, Richard., Robert Small. (1977). Site Planning for Cluster Housing. Van Nostrand Reinhold, Michigan.

Walker, Theodore D. (1990). Plan Graphics - Drawing, Delineation, Lettering. Wiley, New York.

Widodo, Johannes. (1990). Urban Development and the Chinese Settlements in the Northern Coast of Java. 
Jurnal Teknik Arsitektur ARTEKS, Volume. 2, Nomor 1, Juni 2017 ISSN 2541-0598 